UDC 94(477.52): 374.7

DOI: doi.org/10.21272/shaj.2019.i33.p.33

VYACHESLAV O.ARTYUKH ${ }^{1}$, HENNADIYM. IVANUSHCHENKO $^{2}$

${ }^{1} \mathrm{PhD}$ (Philosophy), Sumy State University (Ukraine)

${ }^{2}$ Researcher, Ukrainian Information Service in London(UK)

\title{
SOURCES TO THE HISTORY OF THE EDUCATION SOCIETY 'PROSVITA' IN SUMY (1917-1918)
}

\begin{abstract}
This work is dedicated to the publication and analysis of 15 previously unknown documents from the history of 'Prosvita' society during the Ukrainian Revolution (1917-1918). Some of the documents are now stored in the funds of the State Archive of Sumy Oblast and the Central State Archive of Supreme Authorities and Governments of Ukraine, the another section are newspaper publications in rare editions and a memoir.
\end{abstract}

The contents of the documents testifies that in Sumy the 'Prosvita' Society was established on April 9, 1917 and already on May 21 strongly declared itself, becoming the organizer of the Shevchenko festival. At the same time, the Society made proposals to name one of the city streets by the name of Taras Shevchenko, and erect a monument in memory of him. Sumy 'Prosvita' took an active part in the Ukrainianization of the local state administrations when the Hetman Pavlo Skoropadskyj was a ruler of Ukraine. At 'Prosvita', courses in Ukrainian Studies and Ukrainian were opened for civil servants, teachers and all who were interested. In October 1918, during the discussion around introduction of two state languages in Ukraine - the Ukrainian and Russian, congresses of the 'Prosvita' societies of Sumy district unambiguously had spoken in favour of the Ukrainian language as the only state language and a resolution was sent to Hetman Skoropadskyj. Also, 'Prosvita' constantly had organized literary meeting and concerts, lectures, most often in its premises. Here, the famous Ukrainian writer Hnat Hotkevych had lectured on the history of Ukraine from October 15, 1918. In addition, lectures on national issues here were read by Yakiv Mamontov, V. Kolomiets, Mykola Yukhnovsky. On October 3, 1918, a concert of the famous kobzar Ivan Kuchuhura-Kucherenko was scheduled in the premises of 'Prosvita'. Also, theatrical activity was one of the main activities of 'Prosvita'. Prosvita in Sumy had staged performances at the Korepanov Theatre, which they rented. A Ukrainian choir also perfomed at the 'Prosvita'. In 1918, at the time of the Ukrainian State of Hetman P. Skoropadskyj, the most significant in the activity of Sumy 'Prosvita' was the opening by virtue of his efforts, Ukrainian grammar schools. Grammar schools were started to active in Sumy and in Nyzhnia Syrovatka and Yunakivka villages.

The documents provided make it possible to carry out a reasoned reconstruction of national and cultural life in Sumy during the Ukrainian Revolution, they will undoubtedly interest historians and local historians and will stimulate further research in this direction, as they shed additional light on the history of cultural and educational work in Sumy, as well as wider the role of "Prosvita" in the processes of modern Ukrainian national formation.

Keywords. Sumy, "Prosvita", revolution, Ukrainianization, education, Ukrainian language, theatre, Taras Shevchenko.

\section{B.O. АРТЮХ ${ }^{1}$, Г.М. ІВАНУЩЕНКО}

'Кандидат філософських наук, Сумський державний університет (Україна); ${ }^{2}$ Історик, Українська Інформаційна Служба в Лондоні (Велика Британія)

\section{ДЖЕРЕЛА ДО ІСТОРІЇ ТОВАРИСТВА “ПРОСВІТА” В СУМАХ (1917-1918 рp.)}

Анотація. Ця робота присвячена публікації й аналізу 15 раніме невідомих документів з історії Сумської "Просвіти” доби Украйнської революиії (1917-1921). Зміст документів засвідчує, що в Сумах Товариство "Просвіта" було створено 9 квітня 1917 p. і вже 21 травня голосно заявило про себе, ставши організатором Шевченківського 
свята. Тоді ж Товариством були внесені до міської думи пропозиції назвати одну з вулиць міста іменем Тараса Шевченка, а також поставити йому пам'ятник. "Просвіта" прийняла активну участь в українізаиії державного управлінського апарату за гетьмана Павла Скоропадського. При “Просвіті” були відкриті курси з українознавства та украӥнської мови для державних службовців, вчителів та всіх бажаючих. У жовтні 1918 р. під час розгортання

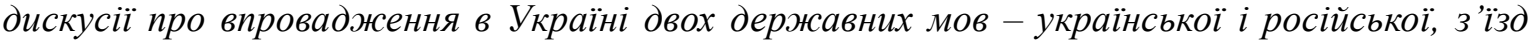
товариств “Просвіт” Сумського повіту однозначно висловися за украӥнську мову як єдину державну і резолюція з изього приводу була направлена гетьманові Скоропадському. Крім того, "Просвіта" постійно організовувала проведення літературних вечірок та концертів, читання лекцій, найчастіше у своєму приміщенні. Театральна справа залишалася одним 3 головних напрямків діяльності “Просвіти”. Сумські просвітяни ставили спектаклі як своӥми власними силами, так і організовували виступи українських труп в орендованому ними театрі Корепанова. При “Просвіті” діяв також украӥнський хор. У 1918 р. найбільш значущзим у діяльності Сумської “Просвіти” було відкриття ї̈ зусиллями українських гімназій у Сумах та селах Нижня Сироватка й Юнаківка.

Ключові слова. Суми, “Просвіта”, револючія, українізачія, освіта, украйнська мова, театр, Тарас Шевченко.

\section{В.А. АРТЮХ}

${ }^{1}$ Кандидат философских наук, Сумской государственный университет (Украина);

${ }^{2}$ Историк, Украинская информационная служба в Лондоне (Великобритания)

\section{ИСТОЧНИКИ К ИСТОРИИ ОБЩЕСТВА “ПРОСВИТА” В СУМАХ (1917-1918 гг.)}

Аннотация. Эта работа посвящуена публикации и анализу 15 ранее неизвестных документов из истории Сумской “Просвитьл” времен Украинской революиии (1917-1921). Содержание документов показывает, что в Сумах общество “Просвита” было создано 9 апреля 1917 и уже 21 мая громко заявило о себе, став организатором Шевченковского праздника. Тогда же Обществом были внесены в городскую думу предложения назвать одну из улиц города именем Тараса Шевченко, а также поставить ему памятник. "Просвита" приняла активное участие в украинизации государственного управленческого аппарата во времена Украинской Державы гетмана Павла Скоропадского. При “Просвите” были открыты курсы украиноведения и украинского языка для государственных служащих, учителей и всех желающих. В октябре 1918 г. во время развертывания дискуссии о внедрении в Украине двух государственных языков украинского и русского, съезд обществ “Просвиты”" Сумского уезда однозначно высказался за украинский язык как единственный государственный и резолюиия по этому поводу была направлена гетману Скоропадскому. Кроме того, “Просвита" постоянно организовывала проведение литературных вечеринок и концертов, чтения лекиий, чаще всего в своем помещуении. Театральное дело оставалась одним из главных направлений деятельности “Просвиты”". Сумские просветители ставили спектакли как своими собственными силами, так и организовывали выступления украинских трупп в арендованном ими театре Корепанова. При “Просвите” действовал также украинский хор. В 1918 г. наиболее значимым в деятельности Сумской “Просвиты” было открытие ее усилиями украинских гимназий в Сумах и селах Нижняя Сыроватка и Юнаковка.

Ключевые слова. Сумы, “Просвита”, револющия, украинизация, образование, украинский язык, театр, Тарас Шевченко.

Процеси модерного націєтворення серед народів Центрально-Східної Свропи за результатами Першої світової війни завершилися для багатьох із них виникненням власних держав. Подібні процеси прослідковуються і в Україні. Тут творення нації на етнічній основі, започатковане в XIX ст., також вивершується виникненням у добу 
Української революції (1917-1921) кількох форм державності (УНР, ЗУНР). У структурі формотворчих чинників нації важливу роль відіграють культурницькі організації, через діяльність яких національно-свідома еліта (найчастіше - інтелігенція) мобілізує народ на створення своєї справді національної культури й держави. Першими організаціями такого типу в Україні були товариства “Громади” (у Києві, Петербурзі, Харкові, Полтаві, Чернігові, Одесі). Після них, починаючи з 60-х років XIX ст. і до початку XX ст., і в Західній Україні, і на Наддніпрянщині виникає ще ціла низка подібних товариств: "Січі", “Соколи”, Українські клуби, наукові товариства, сільські драматичні гуртки. Типологічно до таких організацій належить і товариство "Просвіта". "Просвіта" - одна 3 найстаріших національно-просвітницьких організацій в Україні. Це товариство заснувала 8 грудня 1868 р. у Львові група молодих людей народовського (українського) спрямування. Першим головою “Просвіти” став відомий у Галичині композитор, педагог і журналіст Анатоль Вахнянин (1841-1908). Товариство ставило своїм завданням піднесення національно-культурного та освітнього рівня всіх українців краю. Але крім виконання функцій, що випливають з їх статутних завдань всі ці національно-культурні організації об'єктивно виконували ще одне фундаментальне завдання: вони сприяли вихованню національної самосвідомості широких народних мас, привносячи туди українську ідею, та укріплювали цим самим етнічний фундамент української нації.

За останні 30 років ми маємо досить великий масив історичних досліджень як 3 проблем функціонування "Просвіт" в Україні загалом, так і розкриття ролі та значення діяльності цих організацій в конкретних умовах Української революції. Та, незважаючи на вагомий доробок науковців із зазначеної теми, багато невирішених питань ще залишається. Одним з напрямків подальших досліджень може бути заглиблення аналізу просвітянського руху на первинний, локальний рівень його діяльності, тобто на рівень низових міських і сільських осередків цієї культурно-просвітницької організації. На сьогодні ми вже маємо перші публікації, в яких аналізується специфіка діяльності “Просвіт" як на території сучасної Сумщини, так і конкретно в місті Суми. В. Голубченко спробував подати нарис історії “Просвіт” Сумщини протягом усього XX ст. (Голубченко, 2011). В. Ленський, досліджуючи історію просвітянського руху на Сумщині часів Української революції, робить особливий наголос на діяльності Сумської “Просвіти” (Ленський, 2016). Г. Діброва дослідив історію товариств "Просвіти" в Ромнах та на Роменщині часів Української революції та перших років совєтської влади (Діброва, 2018). В. Нестеренко заторкнув питання функціонування “Просвіт" Сумщини періоду німецької окупації краю (1941-1943) (Нестеренко, 2013). В. Артюх також проаналізував діяльність Путивльської "Просвіти" в цей період (Артюх, 2019). В. Терлецький подав свідчення про передісторію Глухівської "Просвіти" (Терлецький, 1994). А історія Лебединської “Просвіти” часів Української революції розглядається в статті Б. Ткаченка (Ткаченко, 1999).

Велике значення для вивчення ролі “Просвіт” в тогочасному національно-культурному житті має публікація першоджерел: вони становлять ту первинну базу, без якої наукове дослідження неможливе. Крім того, оприлюднення опрацьованих першоджерел має певне значення й для освітянської аудиторії та широкого загалу, бо вони виступають ще й самодостатніми оповідачами, що допомагають самостійно скласти цілісне уявлення про просвітянський рух. І публікація таких джерел з історії просвітянських осередків на Сумщині також вже розпочалася. Так, Г. Іванущенко у своїй книзі “Українське відродження 1917-1920 pp. на Сумщині” опублікував кілька архівних документів, що стосуються діяльності Сумської “Просвіти” (Іванущенко, 2010: 32-33, 60-61, 94, 98).

Мета публікації цих документів, що вперше вводяться до наукового обігу: дати дослідникам джерельну основу для аргументованої реконструкції національнокультурного життя в Сумах часів Української революції. 
Революція 1917 р. підняла на новий рівень процеси національного самоусвідомлення на Сумщині. Тут осередки “Просвіт” були головними “українізаторами" малоросійського народного середовища через систему освіти, бібліотек, театральної i хорової діяльності, курсів українознавства та читання лекцій. Фактично, в цей час осередки “Просвіт" у містах, селах і хуторах були представниками і провідниками волі національного революційного парламенту - Української Центральної Ради.

У Сумах Товариство “Просвіта” було створено 9 квітня 1917 р. (ДАСО. Ф. 2. ОП. 1. Спр. 34: 31). За основу своєї діяльності ним був узятий статут колишньої Одеської “Просвіти”, а почесними членами обрані Михайло Грушевський та Микола Василенко. Очолив просвітянський осередок Василь Покровський. Вже 16 квітня на першому Губернському з'їзді представників Українського народу в Харкові він звітував про заснування та початки діяльності осередку товариства (Губернський, 1917: 2). Проіснувало товариство до початку січня 1919 р. Після захоплення влади в місті 5 січня 1919 р. більшовиками воно свою діяльність вже не відновлювало.

Сумська "Просвіта" вперше голосно заявила про себе під час Шевченківського свята 21 травня 1917 р. (Порядок, 1917: 2). Тоді за результатами мітингу “Просвіта” внесла до міської думи пропозицію назвати одну з вулиць іменем Тараса Шевченка, а також поставити йому пам'ятник. Через рік “Просвіта” своє прохання повторила, додавши до Шевченка ще й ім'я Бориса Грінченка (ДАСО. Ф. 354. Оп. 1. Спр. 56: 33). Таким чином, на символічній карті Сум було започатковано формування шару українськї національної топонімії.

Вже в перший рік свого існування просвітянський осередок м. Суми намагався брати участь і в місцевому політичному житті. Так, у союзі з Українським технічним та агрономічним товариством “Праця" сумська “Просвіта" взяла участь у виборах 30 липня 1917 р. до міської думи. Набрала при цьому, правда, найменше голосів: із 9882 виборців за неї проголосувало всього 112 (ДАСО. Ф. Р-2362. Оп. 1. Спр. 29: 62).

Сумська "Просвіта" прийняла активну участь в українізації державного управлінського апарату за гетьмана П. Скоропадського. При “Просвіті” були відкриті курси з українознавства та української мови для державних службовців, вчителів та всіх бажаючих (ЦДАВО України. Ф. 2201с. Оп. 2. Спр. 374: 5). Прохання створити такі курси Сумська "Просвіта" подала до повітових земських зборів ще наприкінці 1917 р. (ДАСО. Ф. Р-2362. Оп. 1. Спр. 23: 20).

У жовтні 1918 р. під час розгортання дискусії про впровадження в Україні двох державних мов - української і російської з'їзд товариств “Просвіти” Сумського повіту однозначно висловися за українську мову як єдину державну і резолюція з цього приводу була направлена гетьманові Скоропадському (Съезд, 1918: 4).

Крім того, "Просвіта" постійно організовувала проведення літературних вечірок, читання лекцій та концертів, найчастіше у своєму приміщенні. Приміром, відомий літератор Гнат Хоткевич лекції з історії України читав з 15 жовтня 1918 р. Крім того, лекції з національної проблематики читали письменник Яків Мамонтов, В. Коломієць, Микола Юхновський. А на 3 жовтня 1918 р. у приміщенні “Просвіти” був запланований концерт відомого кобзаря Слобожанщини Івана Кучугури-Кучеренка (Український, 1918: 4).

Театральна справа залишалася одним з головних напрямків діяльності “Просвіти”. Сумські просвітяни ставили спектаклі як своїми власними силами, так і організовували виступи українських труп в орендованому ними театрі Корепанова (ДАСО. Ф. 354. Оп. 1. Спр. 56: 23). При “Просвіті” діяв також український хор.

У 1918 р. за часів Української Держави гетьмана П. Скоропадського найбільш значущим у діяльності Сумської “Просвіти” було відкриття іiї зусиллями українських гімназій. Гімназії були започатковані в Сумах та селах Нижня Сироватка й Юнаківка (Гимназия, 1918). Крім того, Сумське товариство в 1918 р. організувало курси української 
мови та курси українознавства, проводило лекції з історії української культури, орендувало приміщення театру Корепанова для проведення своїх вистав, організувало національний хор, намагалося відкрити історико-філологічний факультет в Сумському народному університеті імені Т.Г. Шевченка та книжковий кооператив. Така активна діяльність сумських просвітян була відзначена на четвертому з'їді спілки "Просвіт” Слобожанщини, що проходив 13 жовтня у Харкові (Даниленко, 1918: 3).

Отже, в часи Української революції (1917-1921) в Сумах осередок "Просвіти" забезпечував те культурне піднесення, яке супроводжувало національно-визвольні змагання, а просвітянський рух став основною організаційною формою залучення широких верств населення до активної участі у цих процесах. "Просвіта” виступила активним пропагандистом і популяризатором національних, культурних i духовних цінностей, докладала чимало зусиль для формування української національної ідентичності місцевого населення.

Документи публікуються мовою оригіналу зі збереженням мовних особливостей того часу: орфографії та елементів застарілої лексики для відтворення специфіки історичної доби (наприклад, збережено застосування літер “e”, “i”” замість “є”, “i”, що пояснюється елементарною відсутністю цих останніх літер, притаманних лише українській мові, у гарнітурах шрифтів тогочасних друкарень; ця ж проблема стосується і шрифтів на друкарських машинках). Описки виправляються без застережень. Подекуди, згідно 3 нормами сучасного правопису, розставлені розділові знаки. Помітки й резолюції на документах, як правило, опускаються.

Сподіваємося, що подані нижче джерела зацікавлять краєзнавців та будуть стимулювати подальші дослідження в цьому напрямку, оскільки проливають додаткове світло на історію культурно-освітньої роботи в Сумах, а також, ширше, ролі “Просвіти” в процесах модерного українського націєтвотворення.

Література:

Артюх, 2019 - Артюх В. Путивльська “Просвіта" в 1941-1943 рр. // Сумські історико-краєзнавчі студії. Збірник матеріалів Регіональної науково-практичної коференції. Суми, 2019. С. 28-32.

Берестовський, 1917 - Берестовський I. До українців // Сумской вестник. 1917. № 183 (22 августа). С. 4. Гимназия, 1918 - Гимназия в Вер. Сыроватке // Земские известия. 1918. № 44 (12 сентября).

Голубченко, 2011 - Голубченко В. "Просвіта" Сумщини в контексті формування національної самосвідомості: історія та сучасність // Світогляд-Філософія-Релігія: Зб. наук. пр. Суми, 2011. № 1. С. $221-230$. Гребенщиков, 2009 - Воспоминания генерала Сергея Яковлевича Гребенщикова. Симферополь, 2009. 344 с.

Губернський, 1917 - Губернський український з”їзд в Харькові // Рідне слово. 1917. № 4 (22 квітня). С. 2 Даниленко, 1918 - Даниленко К. Четвертий з'їзд Спілки “Просвіт” Слобожанщини в м. Харькові // Земське діло. 1918. № 345 (28 жовтня). С. 3.

Діброва, 2018-Діброва Г.В оборонірідного краю(З історіїроменської“Просвіти” 1917-1924 pр.)// Літературномистецькі та історичні контексти формування національної державності в добу Української революції 1917-1921рр. та їх педагогічна інтерпретація в сучасній освітній діяльності: матеріали обласної науково-практичної конференції, 21 березня 2018 року. Суми, 2018. C. 101-108. URL: http://www.soippo.edu.ua/images/ \% D $0 \% 9$ D \% D 0\% B E \% D 0\% B 2\% D 0\% B 8\% D 0\% B D \% D 0\% B 8/2018/03/23/novost 4 / $\% \mathrm{D} 0 \% 9 \mathrm{C} \% \mathrm{D} 0 \% \mathrm{~B} 0 \% \mathrm{D} 1 \% 82 \% \mathrm{D} 0 \% \mathrm{~B} 5 \% \mathrm{D} 1 \% 80 \% \mathrm{D} 1 \% 96 \% \mathrm{D} 0 \% \mathrm{~B} 0 \% \mathrm{D} 0 \% \mathrm{BB} \% \mathrm{D} 0 \% \mathrm{~B} 8 . \mathrm{pdf}$ (датазвернення 21.12 .19 ). ДАСО - Державний архів Сумської області.

Іванущенко, 2010 - Українське відродження 1917-1920 рр. на Сумщині / автор-упорядник Іванущенко Г.М. Суми, 2010. Т. 1.280 с.

Кириєвський, 2017 - Кириєвський В. Українська весна в Шостці // Слово Просвіти. 2017. 21 квітня.

Ленський, 2016 - Ленський O. Про початки товариства "Просвіта" на Сумщині // Сумський краєзнавчий збірник. Суми, 2016. С. 205-211.

Нестеренко, 2013 - Нестеренко В. Товариства “Просвіта” на Сумщині в роки окупації (1941-1943 pp.) // Суспільно-політичні процеси на українських землях: зб. матер. II Всеукр. наук.-практ. конф., м. Суми, 21 травня 2013 р. Суми, 2013. С. 41-43.

Покровський, 1917 - Покровський В. Суми, 21-го травня // Сумской вестник. 1917. № 109 (21 мая). С. 4 Порядок, 1917 - Порядок украинскго праздника // Сумской вестник. 1917. № 109 (21 мая). С. 2. 
Протест, 1917 - Протест проти відокремлення Харьківщини // Нова Рада. 1917. № 134 (10 вересня). С. 3.

Съезд, 1918 - Съезд просвит // Луч. 1918. № 96 (9 октября). С. 4.

Терлецький, 1994 - Терлецьький В. До питання про глухівську “Просвіту” // Глухівщина. 1994. 19 грудня.

Ткаченко, 1999 - Ткаченко Б. Лебединський гурток “Просвіта" // Життя Лебединщини. 1999. 20 січня.

ЦДАВО України - Центральний державний архів вищих органів влади та управління України.

Український, 1918 - Український концерт // Луч. 1918. 3 жовтня. С. 4.

\section{References:}

Artiukh, 2019 - Artiukh V. Putyvlska "Prosvita" v 1941-1943 rr. [Putivl's “Prosvita" in 1941-1943] // Sumski istoryko-kraieznavchi studii. Zbirnyk materialiv Rehionalnoi naukovo-praktychnoi koferentsii. Sumy, 2019. S. 2832. [in Ukrainian].

Berestovskyi, 1917 - Berestovskyi I. Do ukraintsiv [To the Ukrainians] // Sumskoi vestnyk. 1917. № 183 (22 avhusta). S. 4. [in Ukrainian].

Gimnaziya, 1918 - Gimnaziya v Ver. Syrovatke [Gymnasium in the Verhniaya Syrovatka]// Zemskie izvestiya. 1918. № 44 (12 sentyabrya). [in Russian].

Holubchenko, 2011 - Holubchenko V. "Prosvita" Sumshchyny v konteksti formuvannia natsionalnoi samosvidomosti: istoriia ta suchasnist ["Prosvita" of Sumy in the context of formation of national consciousness: history and modernity] // Svitohliad-Filosofiia-Relihiia: Zb. nauk. pr. Sumy, 2011. № 1. S. 221-230. [in Ukrainian].

Grebenshikov, 2009 - Vospominaniya generala Sergeya Yakovlevicha Grebenshikova [Memoirs of General Sergey Yakovlevich Grebenshchikov]. Simferopol, 2009. 344 s. [in Russian].

Hubernskyi, 1917 - Hubernskyi ukrainskyi zizd v Kharkovi [Provincial Ukrainian Congress in Kharkiv] // Ridne slovo. 1917. № 4 (22 kvitnia). S. 2. [in Ukrainian].

Danylenko, 1918 -Danylenko K. Chetvertyi zizd Spilky "Prosvit" Slobozhanshchyny v m. Kharkovi [The fourth congress of the Prosvita Union of Slobozhanshchina in Kharkiv] // Zemske dilo. 1918. № 345 (28 zhovtnia). S. 3. [in Ukrainian].

Dibrova, 2018 - Dibrova H. V oboroni ridnoho kraiu (Z istorii romenskoi "Prosvity" 1917-1924 rr.) [In defense of the native land (From the history of the Romany "Prosvita" 1917-1924)] // Literaturno-mystetski ta istorychni konteksty formuvannia natsionalnoi derzhavnosti v dobu Ukrainskoi revoliutsii 1917-1921 rr. ta yikh pedahohichna interpretatsiia $\mathrm{v}$ suchasnii osvitnii diialnosti: materialy oblasnoi naukovo-praktychnoi konferentsii, 21 bereznia 2018 roku. Sumy, 2018. C. 101-108. URL: http://www.soippo.edu.ua/images/ $\%$ D $0 \% 9$ D \% D 0 \% B E \% D 0\% B 2\% D 0\% B 8\% D 0\% B D \% D 0\% B $8 / 2018 / 03 / 23 /$ novost $4 /$ $\% \mathrm{D} 0 \% 9 \mathrm{C} \% \mathrm{D} 0 \% \mathrm{~B} 0 \% \mathrm{D} 1 \% 82 \% \mathrm{D} 0 \% \mathrm{~B} 5 \% \mathrm{D} 1 \% 80 \% \mathrm{D} 1 \% 96 \% \mathrm{D} 0 \% \mathrm{~B} 0 \% \mathrm{D} 0 \% \mathrm{BB} \% \mathrm{D} 0 \% \mathrm{~B} 8$.pdf (data zvernennia 21.12.19). [in Ukrainian].

DASO - Derzhavnyi arkhiv Sumskoi oblasti [State archive of Sumy region].

Ivanushchenko, 2010 - Ukrainske vidrodzhennia 1917-1920 rr. na Sumshchyni [Ukrainian Revival of 19171920 in Sumy Region] / avtor-uporiadnyk Ivanushchenko H.M. Sumy, 2010. T. 1. 280 s. [in Ukrainian].

Kyryievskyi, 2017 - Kyryievskyi V. Ukrainska vesna v Shosttsi [Ukrainian Spring in Shostka] // Slovo Prosvity. 2017. 21 kvitnia. [in Ukrainian].

Lenskyi, 2016 - Lenskyi O. Pro pochatky tovarystva "Prosvita" na Sumshchyni [About the beginnings of the association "Prosvita" in Sumy region] // Sumskyi kraieznavchyi zbirnyk. Sumy, 2016. S. 205-211. [in Ukrainian].

Nesterenko, 2013 - Nesterenko V. Tovarystva "Prosvita" na Sumshchyni v roky okupatsii (19411943 rr.) [Prosvita Society in Sumy Region during the Occupation (1941-1943)] // Suspilno-politychni protsesy na ukrainskykh zemliakh: zb. mater. II Vseukr. nauk.-prakt. konf., m. Sumy, 21 travnia 2013 r. Sumy, 2013. S. 41-43. [in Ukrainian].

Pokrovskij, 1917 - Pokrovskij V. Sumi, 21-go travnya [Sumy, May 21] // Sumskoj vestnik. 1917. № 109 (21 maya). S. 4. [in Ukrainian].

Poryadok, 1917 - Poryadok ukrainskogo prazdnika [The order of the Ukrainian holiday] // Sumskoj vestnik. 1917. № 109 (21 maya). S. 2. [in Russian].

Protest, 1917 - Protest proty vidokremlennia Kharkivshchyny [Protest against separation of Kharkiv region] // Nova Rada. 1917. № 134 (10 veresnia). S. 3. [in Ukrainian].

Sezd, 1918 - Sezd prosvit [Congress of Prosvita] // Luch. 1918. № 96 (9 oktyabrya). S. 4. [in Russian].

Terletskyi, 1994 - Terletskyi V. Do pytannia pro hlukhivsku "Prosvitu" [On Hlukhiv "Prosvita"] // Hlukhivshchyna. 1994. 19 hrudnia. [in Ukrainian].

Tkachenko, 1999 - Tkachenko B. Lebedynskyi hurtok "Prosvita" [Lebedin society "Prosvita"] // Zhyttia Lebedynshchyny. 1999. 20 sichnia. [in Ukrainian].

TsDAVO Ukrainy - Tsentralnyi derzhavnyi arkhiv vyshchykh orhaniv vlady ta upravlinnia Ukrainy [Central State Archive of Higher Authorities and Administration of Ukraine].

Ukrainskyi, 1918 - Ukrainskyi kontsert [Ukrainian concert] // Luch. 1918. 3 zhovtnia. S. 4. [in Russian]. 


\section{Програма Шевченківського свята в Сумах 21 травня 1917 p.}

\section{Порядок Украинского праздника}

21 травня 1917 року

В 11 часов с площади перед Духовным училищем по Троицкой улице направляются в город 1) рабочие бельгийского завода, 2) ученики сельско-хозяйственной школы, 3) рабочие павловского завода, 4) крестьяне с. Луки и Барановки, 5) рабочие завода Погуляченко и Гвоздь, 6) лазареты красного креста и земской больницы.

Возле главной конторы Харитоненко в перечисленным группам присоединяются служащие конторы и делегация чехов и процессия направляется к городской управе, где ее встречает рада "Просвиты”, представители города, земства и общественного комитета. Последние приветствуют здесь процессию. Тут же присоединяются к процессии торгово-промышленники, купцы и служащие в торгово-промышленных заведениях и направляются к собору, где их встречает духовенство. От собора шествие направляется к Покровской площади, где будет отслужена панихида по Т.Г. Шевченко.

(Порядок, 1917: 2).

\section{Документ № 2 \\ Стаття керівника “Просвіти” Василя Покровського з нагоди Шевченківського свята в м. Суми}

\section{Суми 21-го травня}

21 травня 1917 року

Всякому лиху буває край, і ми знаємо, що після лиха знов прийде радість; які б густі хмари не обступали нас, та ми знаємо, що вітер розвіє їх і знов безмірне блакитне небо обійме і приголубе землю, знов усміхнеться з гори яснеє сонце і за ним усміхнеться від щастя всяка жива істота. Без надії на світлу будучину не можно було б жити на світі і краще людині смерть, коли в душі погасає остання іскра надії і залишається одне холодне зневірря.

Тяжке і здавалось безпросвітне лихо панувало на Вкраїні від лих і кайданів, які кували їй царі-кати і їх прислужники майже на протязі 3-х століть! Все стогнало, все сумувало од краю й до краю на всім просторі нашої землі. Сумували люде, сумували степи, на яких "родилась $\mathrm{i}$ гарцювала козацька воля", сумували “могили-гори” - що тільки з вітром розмовляли, згадуючи тих, котрі кров'ю і життям своїм заплатили за любов до рідного краю; сумував Дніпро і його кручі, сумувала на ціх кручах і та могила, яка притягала до себе серця і думки вірних синів нашого народу. Безмірний був сум, але іскра надії на кращу долю ніколи нас не покидала i боронила нас від того одчаю, за яким уже настає смерть. Таку надію кохав у свойому серці i наш незрівняний геній Т. Г. Шевченко, що пророчим оком своїм передбачав той час, коли він “і Дніпро і кручі - все покине і полине до самого Бога молитися... за Вкраїну", а огненне його “слово" завше було на сторожі коло “малих оттіх рабів німих", душу якіх готов був заморозить холод одчаю.

Та лихо минуло... Нема катів, тюрмів й кайданів і знов ми вільні сини вільнолюбної нашої Матері-Вкраїни, на всім просторі якої одправляється сьогодні Велике свято національного Відродження. Чиє ж серце тріпочеться від щастя й радості під час цього свята?

3 цім щастям, 3 цією радістю й здоровлю Вас всіх сестри й брати мої українці! Ще не все зроблено, ще буде сум, буде й боротьба з темними силами, але сьогодні, під час свята нашого Воскресіння, геть сум і нехай по всій Україні лунають тільки радісні побідні гімни: де твоє, смерте, жало? Де твоя, пекло, побіда? Смерті празднуємо умерщвлєніє!

Ще раз бажаю, щоб часта радість Ваша і чисте Ваше щастя, сестри й брати мої, нічим не були засмучені сьогодні, і щоб цей день назавше залишився в Ваших спогадах як один 3 найсвітліших днів нашого життя! 
Документ № 3

Уривок з газети “Сумской вестник” із закликом до українців активізувати свої націєтворчі зусилля

До українців

22 серпня 1917 року

Сумською радою т-ва "Просвіти” на 11 серпня назначались в земстві загальні збори.

Всіх членів т-ва "Просвіта" зьявилось на зібрання всього до 30 осіб. Голова ради Покровський зробив обьяву, що при такому числі неможливо відчинить зібраннє, бо треба в згоді з статутом найменше 100 особ, через те, що всіх членів налічується більше 200. Призначені другі загальні збори в тому же земстві на 27 серпня (августа).

Щирі українці, до вас моє слово, до вас мій заклик. Життя по всій Россії хвилює, будуються скрізь нові порядки, нові закони, єднаються до куп і міцно працюють на користь рідного краю, всієї Россії і нашої неньки України.

I. Берестовський. (Берестовський, 1917: 4).

\section{Документ № 4 \\ Повідомлення про лист Сумської “Просвіти" до Центральної Ради з протестом проти спроб відокремити Харківську губернію від України}

10 вересня 1917 року

Протест проти відокремлення Харьківщини. Сумське товариство «Просвіта»на Харьківщині послало до Центральної Ради такого листа:

“"Загальні збори сумського товариства “Просвіта", протестуючи проти відокремлення Харьківщини від Автономної України, сподіваються, що Центральна Рада, як оборонець народних прав, вживе всіх заходів для об’єднання вилучених частин української території в єдину Автономну Україну"2.

(Протест, 1917: 3).

\section{Документ № 5}

Лист від Сумської “Просвіти” до повітової земської управи з висвітленням завдань цієї організації та проханням про виділення коштів для бібліотеки

\section{В СУМСЬКУ ПОВІТОВУ ЗЕМСЬКУ УПРАВУ}

23 листопада 1917 року

В квітні цього року в Сумах заснувалось Украінське товариство "ПРОСВIТА" мета котрого культурно-просвітна діяльність серед темного нашого “найменшого брата".

Головним чином "ПРОСВIТА" має знайомити люд український з його рідною історіею, літературою і музикою, а також найбільш зрозумілим способом - поширювати проміж нього всякі агрономичні, техничні і сільсько-господарські відомості. Для сього “ПРОСВІТА” одкрила в Сумах Українську бібліотеку-читальню і невеличку книгарню, в якій з охотою купують писані вкраїнською мовою книжки, як літературного змісту, так і спеціального по ріжним галузям сельського господарства. Окрім того “ПРОСВІТА” мае впоряжати лекціі, литературно-вокальномузичні вечірки, театральні вистави і инші розумні розваги як для дорослих, так і для дітей; але на все це треба багато грошей, котрих бракує у "ПРОСВІТИ".

Беручи на увагу, що діяльність “ПРОСВІТИ" однакова з діяльністю відділа позашкільної освіти при Сумському Земстві, і що “ПРОСВITА” таким чином допомогае Земству сіяти світ серед темних народніх мас, Рада "ПРОСВІТИ" в засіданні свойому 11го листопаду постановила просити у Сумського Повітового Земства грошової допомоги в 5000 рублів (на побильшення библіотеки-читальні - 3000 р. і на утворення спеціяльного капиталу на куплю книжок для продажу - 2000 р.). 
Виконуючи постанову “РАДИ”, маю честь просити Сумську Земську Управу доложити про вищенаведене прохання найближчому зібранню п. п. гласних Сумського Земства. 1917 р. Листопаду 22 дня.

ГОЛОВА "РАДИ” [Василь Покровський]

ДАСО. Ф. 2. Оп. 1. Спр. 34: 31. Оригінал. Машинопис.

\section{Документ № 6 \\ Доповідь Сумської повітової земської управи Сумським повітовим земським зборам за клопотанням Українського Товариства "Просвіта" про призначення їй одноразової грошової допомоги}

Кінець 1917 року*

Украинское товарищество “Просвіта" обратилось в Земскую Управу с просьбой ходатайствовать перед Собранием о назначении ему пособия в размере 5000 руб. (3000 р. на пополнение имеющейся при названном товариществе “Просвіта” библиотеки-читальни и 2000 руб. на образование специальнаго капитала на покупку книг для продажи. Целью своею “Просвіта", как видно из ея заявления ставит знакомить украинское население с его родной историей, литературой и музыкой, а также распространение среди населения доступных знаний по агрономии, технике и сельскому управлению и наконец предоставлять разумные развлечения, как взрослому населению, так и детям: устранивать лекции, литературно-вокально-музыкальные вечера, спектакли и т.п.

Словом, “Просвіта" своей деятельностью приходит тут на помощь отделу по внешкольному образованию при Сумском Земстве.

Сумская Уездная Училищная Комиссия в заседании 21-го Декабря 1917 года, заслушав заявление “Просвіты”, постановила просить Управу ходатайствовать передь Земским Собранием о назначении означенному товариществу пособия на указанный предмет в размере 5000 руб. с тем условием, чтоб в числе членов правления “Просвіты” был представитель от Земства по выбору Земскаго Собрания.

Исходя из тех соображений, что самой Управой с этого года намечается открытие книжнаго склада для продажи населению уезда книг и что библиотека-читальня при “Просвіте” будет обслуживать главным образом население города, который, по мнению Управы, и должен прийти на помощь этой библиотеке. Управа находить нужным просить Собрание удовлетворить ходатайство Украинскаго Товарищества “Просвіта" только отчасти, назначить ему в единовременное пособие 1000 руб., которые внести в смету 1918 года и избрать представителя от Земства в правление означеннаго Товарищества.

Подлинный за надлежащими подписями.

Полагаю возможным ходатайствовать о выдаче пособия в размере 5000 руб., избрать от Земскаго Собрания представителя в Правление “Просвіти” и обязать “Просвіту” представить Земскому Собранию отчет в израсходовании пособия

Подлинное за подписью Члена Управы И. Нечипоренко.

С подлинным верно:

Председатель Управы

Член Управы [Підпис]

Секретарь [Підпис]

ЦДАВО України. Ф. 2201с. Оп. 2. Спр. 362: 13-13зв. Завірена копія. Машинопис.

*Датування за змістом документу. 


\section{Документ № 7 \\ Рішення Сумської повітової земської управи про надання "Просвіті" приміщення для репетицій}

11 січня 1918 року

\begin{tabular}{c|l}
$\begin{array}{c}\text { №o } \\
\text { по } \\
\text { порядку } \\
4 .\end{array}$ & \multicolumn{1}{|c}{ Слушали: } \\
& [...] Ходатайство Сумского \\
& Украинского Товарищества имени \\
& Т. Г. Шевченко о предоставлении \\
& ему помещения в Сумском 2-х \\
& классном земском женском \\
& училище для репетиций как \\
& хоровых, так и сценических. \\
\hline
\end{tabular}

4) Предоставить Сумскому Украинскому Товариществу имени Т. Г. Шевченко помещение в женском 2-х классном училище, с тем, что уплату вознаграждения прислуге училища Рада Просвиты принимает на себя. [...]

ДАСО. Ф. 2. Оп. 1. Спр. 35: 83в.-9. Оригінал. Машинопис.

\section{Документ № 8}

Договір Сумської земської повітової управи 3 "Просвітою" про здавання під найм товариству двох кімнат, арендованих земством у будинку Бережного

14 червня 1918 року

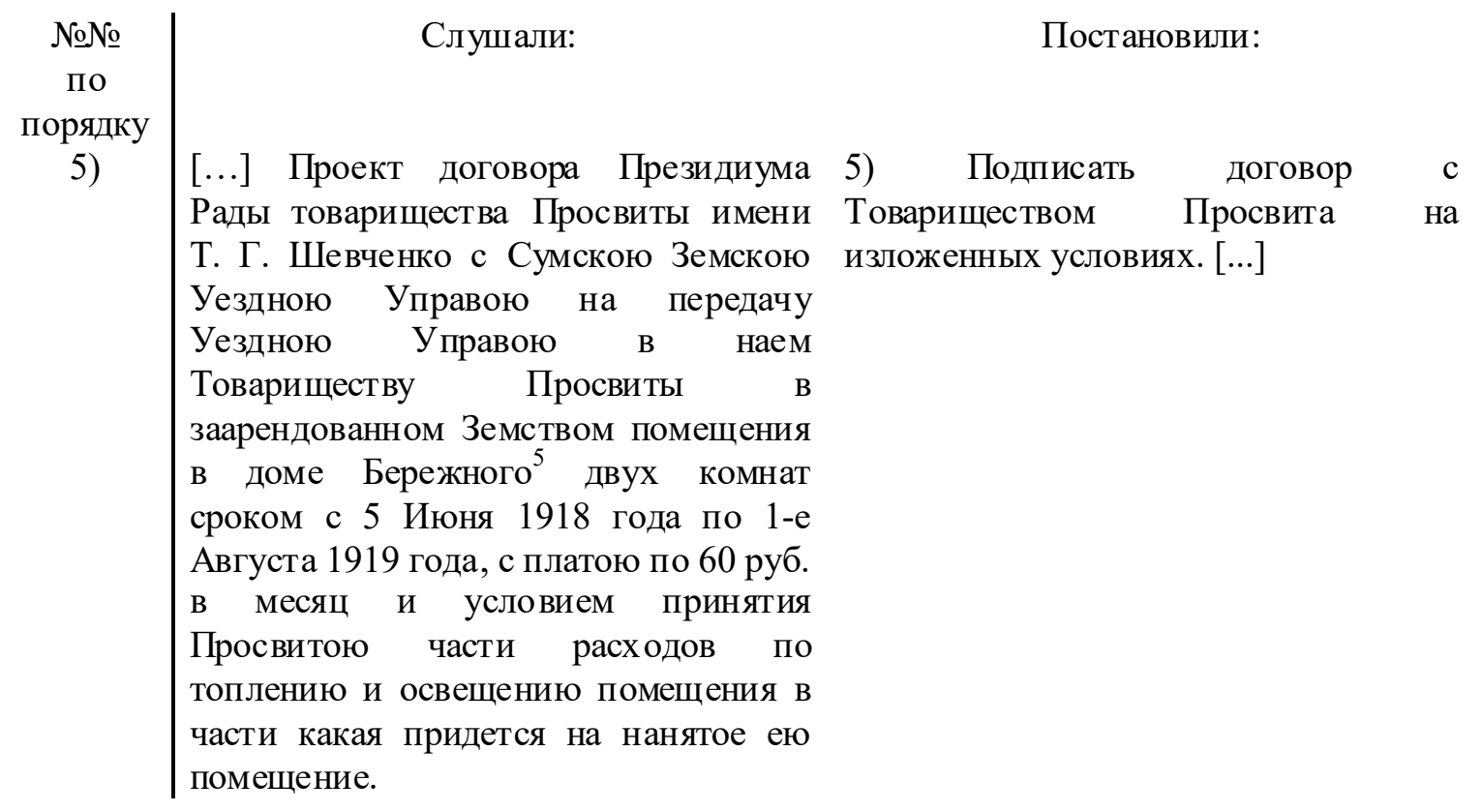

ДАСО. Ф. 2. Оп. 1. Спр. 35: 154зв.-155зв. Оригінал. Машинопис. 
Клопотання Товариства "Просвіта" до Сумської міської думи про перейменування вулиці Соборної на вулицю Т. Г. Шевченка та про вставлення бюсту Шевченка

До Мійської Думи м. Сум

28 травня 1918 року

На загальних зборах Т-ва “Просвіта" ім. Т.Г. Шевченка 8 квітня с. р. постановлено: прохати Думу Соборну вул. переіменовать у вулицю Тараса Шевченка, поставити бюст Т.Г. Шевченка у м. Сумах проти 1-ї жіночої гимназії ${ }^{4}$, а також назвати Червону Школу іменем українського пісьменника і педагога Бориса Грінченка, про що прізідія загальних зборів Т-ва "Просвіти" доводить до відому Мійської Думи.

Голова зборів [Підпис]

Писарь [Підпис]

ДАСО. Ф. 354. Оп. 1. Спр. 56: 33. Оригінал. Машинопис на бланку.

\section{Документ № 10 \\ Відношення Сумської “Просвіти” до Міністерства народної освіти 3 повідомленням про відкриттям нею курсів українознавства та української мови}

До Пана Директора Позашкільноі Освіти Міністерства Народньоі Освіти і Мистецтва

12 серпня 1918 року

Украінськоі Держави.

Рада Товариства "Просвіти" у м. Сумах доводючи до Вашого відому, що нашим товариством засновані курси украінознавства імени І. М. СТЕШЕНКА ${ }^{6}$, а також окремо курси Украінськоі мови (у першій групі в числі 70 ч. слухачів заняття вже давно розпочалися, друга група засновуеться, яка буде приблизно в тому ж числі слухачів) ласкаво прохае Вас, Пане Добродію, повідомити чи мае право Рада Т-ва видати посвідчення слухачам, які прослухають вищезазначені курси

Голова Ради [Колодяжний ${ }^{8}$ ]

Писарь [Підпис нерозбірливий]

ЦДАВО України. Ф. 2201с. Оп. 2. Спр. 374: 5. Оригінал. Машинопис.

\section{Документ № 11 \\ Повідомлення про відкриття Сумською “Просвітою" гімназії в с. Верхня Сироватка}

Гимназия в Вер. Сыроватке

12 вересня 1918 року

Товарищество рады “Просвіти”, открывает в с. Верхней Сыроватке украинскую гимназию. Гимназия будет иметь только первых три класса.

Начало занятий также, как и в остальных правительственных учреждениях. Плата за правоучение взимается в размере 250 р. Дети бедных могутъ учиться бесплатно, при условии если их успехи будутъ хороши.

Окончившие одноклассные учебн[ые] завед[ения] принимаются в 1-й класс без экзамена, окончившие двухклассное учил[ище] могуть поступать во 2-й класс. 


\section{Документ № 12 \\ Оголошення про концерт кобзаря Івана Кучугури-Кучеренка}

\section{Украинскій концерт}

3 жовтня 1918 року

Після свого артистичного турне по Просвітам Полтавщини, де відбулося 36 концертів, 2го сього жовтня до Сум завітав славнозвісний кобзарь Іван Кучугура-Кучеренко який має намір упорядити ряд концертів по Просвітам Сумщини. Будуть виконані історичні думи й пісні.

Сегодня 3-го жовтня в помешканні Т-ва Просвіти відбудеться концерт Кучеренка при участі артиста Василя Павловича Цимбала, який прочитає реферат: “Про кобзу, кобзарів, историчні й народні пісні”, а також продеклямує з Франка, Грінченка, Олеся й инших поетів.

Початок о 8-ми годині.

(Український, 1918: 4).

\section{Документ № 13}

\section{Резолюція з'їзду представників Товариства "Просвіта" Сумського повіту стосовно державності української мови}

\section{Съезд просвит}

9 жовтня 1918 року

В воскресенье, 6 октября днем в помещении местной “Просвіти” состоялся съезд представителей всех Товариществ "Просвіта" Сумского уезда, на котором обсуждались некоторые назревшие вопросы организации Товариществ и просветительной деятельности их и, в конце котораго, была вынесена следующая резолюция, принятая единогласно:

“До Пана Голови Ради Міністрів Украінскоі Держави". Ми, презідіум з'ізду Просвіт Сумщини на Харьківщині, який одбувся 6 жовтня (нов[ого] ст[илю]) маємо за честь прохати Вашу Вельможність при службовому докладі Ясновельможному Пану Гетьманові доложити також і цю постанову вищезазначеннаго з'ізду Просвіт Сумщини.

Постанови з' ізду Просвіт Сумщини від 6-го жовтня н[ового] с[тилю] відносно державноі мови.

1) Ознакомившись зі змістом відомого меморандуму Киівскоі Просвіти про Украінську мову, ми вважаємо необхідним підтримати й приєднатись до нього, як до вислову наших думок, що до Украінського слова.

2) Украінська мова в Українській державі повинна бути Державною.

3) Українська мова повинна бути обов'язковою по всіх урядових та громадських публичноправових інституціях. школах.

4) Необхідно звернути особливу увагу на викладання украінскоі мови й украінознавства в

5) Ворожі виступи, навіть урядовців, проти українскої мови, яко мови Державноі вважаємо за виступ проти Украіни.

6) На Сумщині зараз книжковый голод на українські підручники за для низчих і середних шкіл - прохати украинський уряд садовольнити цю культурну потребу виданням укр. підручників.

7) Прохати Пана Голову Ради Міністрів цю резолюцію з'ізда Просвіт доложити Ясновельможному Пану Гетьманові всієї Вкраіни".

За надлежащими подписями резолюция была послана в Киев в тот же день.

(Съезд, 1918: 4).

Документ № 14

Звіт про четвертий 3’їзд Спілки “Просвіт” Слобожанщини в м. Харків 13.10.1918

28 жовтня 1918 року

На з'ізд прибули представники від усіх повітів Харьківщини, числом до 50, і заступали собою до сотні просвітніх організацій, та ще делеговано на з’ізд від десятка районих громадських установ м. Киіва і Харькова. 
В презідію з'ізду обрано: головою - доб. Бутенка, заступником - доб. Кравченка, писарем - Костя Даниленка, почесним головою зізду професора М. Сумцова. Від імени ради "Спілки Просвіт”, робить доклад про іі діяльність доб. М. Кекало. Доклад по змісту - небагатий, одноманітний, по наслідкам праці - невідрадний, бо Рада далі, як по за межі звичайної собі канцелярщині: одсилка інформацій, листування з сілськими Просвітами, - нічогісенько більше не зробила, інструкторів в цей період не було, бо спілка мало одержувала членські внески і відсотки, а від земства і иньших громадських інституцій грошей не одержували, міністерство освіти на наше прохання помочи, ще й досі не зібралось дати відповідь. Зараз спілка «Просвіт», має порожню скарбницю: матеріальні недостачи всьому виною!

Позатим було відчитано двадцять докладів з місць. Доклади - ріжнобарвні, цікаві по змісту, по наслідках роботи - часами сумні, часами бадьорі! Всю освітню роботу можно поділити на чотирі категоріi, а саме: просвітню, бібліотекарську, дикційну і драматичну. Майже кожна 3 «Просвіт» заходилась відкривати бодай короткострочні курси, вечірні, або недільні школи по украінознавству, вдержує невеличкі книгозбірні-читальні, виписує газети та журнали, старалася закликати українських лекторів, докладчиків, референтів і т. д., але все таки на першому місці стоять: вистави, концерти й співи і драматична секція зробила так багато, як усі останні категоріі, взявши іх до купи! Докладчики поясняють, що вистави одиноке джерело, звідки черпається на всі нижчі просвітянські потреби. Можно з певністю сказати, що на Харьківщині немає зараз такого міста, слободи, села де б не відбувалися вистави-аматори, з села ідуть на хутори і розливається всюди широкими потоками рідне слово-пісня! Найкраще поставлена просвітянська справа у Вовчанському і Сумському повітах на Харьківщині. Щоб вишукати і притягти до праці свідомих, діяльних украіців у Вовчі робота поділена на багато окремих груп: просвітню, театральну, лекційну, музично-хорову, бібліотечну, редакційну і т. д. Просвіта видає спеціяльно свій часопис (тижневик) "Світло", - а всі просвіти в повіті єднаються навколо своєі “матері-просвіти” у Вовчій на взірець Львівськоі. Мається і иструктор по організаціі Просвіт на селах! Сумська повітова Просвіта, відчиняла недавно аж двічі курси украінськоі мови, які пройшли там 3 великим успіхом, читаються лекціі про "Українську культуру" то що, а для вистав заорендовано Просвітою місцевий театер. При Сумському народньому університеті Просвіта гадає відкрити украінський історико-фільольогічний факультет, а також украінску гімназію і книжний кооператив; зараз гуртується національний хор. Недавно відбувся повітовий з'ізд, який вирішив - об'єднатися в повітову “Спілку Просвіт”, а для організації Просвіт удержується інструктор на повіт. 3 осередку розкидати в іх ті національні свідомости по селах - ось завдання Сумськоі повітовоі Просвіти! [...]

Писарь Кость Даниленко. (Даниленко, 1918:3).

\section{Документ № 15 \\ Прохання Товариства "Просвіта" до Сумської міської управи увільнити їхній спектакль від грошового податку}

До Сумської мійської

6 грудня 1918 року

Управи

Рада Т-ва Просвіти ласкаво прохає увільнити наш спіктакль від 29 листопаду у театрі Корепанова від городського налогу, маючи на увазі благодійну мету спектаклю, котрий улаштовувався на користь военно-полонених солдат.

Голова [Підпис]

Писар [Підпис]

ДАСО. Ф. 354. Оп. 1. Спр. 56: 23. Оригінал. Рукопис на бланку.

\section{Коментарі}

${ }^{1}$ Покровський Василь - перший керівник Сумської “Просвіти”. Про нього нам відомо, що у 1917 р. йому було 53 роки, проживав він у місті на вул. Бельгійська, 18 та був членом міської управи. - Док. № 2 . 
24 серпня 1917 р. російський Тимчасовий уряд видав “Тимчасову інструкцію Генеральному Секретаріатові Тимчасового уряду”, за якою обмежувалось дія повноважень виконавчого органу Української Центральної Ради Генерального Секретаріату територіями Волинської, Київської, Подільської, Полтавської і частково Чернігівської губерній. Таким чином, Харківська губернія була виведена із-під юрисдикції Генерального секретаріату, що спричинило вибух невдоволення серед національно-свідомих сил Слобожанщини. Виступаючи на Першому Всеукраїнському з'іздді “Просвіт”, голова Сумської “Просвіти” В. Покровський ще раз підкреслив, що “Просвітою було вжито всіх заходів, щоб Харківщину було прилучено до України” (ЦДАВО України. Ф. 2581. Оп. 1. Спр. 157: 35зв). - Док. № 4.

${ }^{3}$ В результаті Сумська повітова народна управа заклала у видатки на 1918 р. одноразову допомогу “Просвіті” (на книгозбірню) у розмірі 1000 карбованців (ШДАВО України. Ф. 2201с. Оп. 2. Спр. 362: 5). - Док. № 6.

${ }^{4}$ Будинок Бережного - зараз це будинок на площі Покровській, 11. У цьому будинку до революції знаходився готель “Версаль” і до 1913 р. в ньому арендував собі кілька кімнат Малоросійський гурток любителів драматичного та музичного мистецтв, а в 1942 р. тут розташовувались українські організації і під прикриттям “Просвіти” діяло підпілля революційної ОУН на чолі з Семеном Сапуном. - Док. № 8.

${ }^{5}$ Вулиця Соборна була перейменована на вулицю Тараса Шевченка вже більшовиками 5 липня 1920 p., а пам'ятник Т. Шевченкові роботи Івана Кавалерідзе навпроти І-ої жіночої гімназії був встановлений у 1926 р. - Док. № 9.

${ }^{6}$ Стешенко Іван (1873-1918) - член Центральної Ради, генеральний секретар освіти. Здійснював українізацію шкільництва. Був убитий у Полтаві 30 липня 1918 р., як виявилося пізніше, більшовиками. - Док. № 10.

7 Департамент позашкільної освіти 31 серпня повідомив Сумську “Просвіту”, “що Рада Т-ва має право видавати посвідчення, але вони не будуть мати офіціального значіння, а лише моральне” (ЦДАВО України. Ф. 2201с. Оп. 2. Спр. 374: 6). - Док. № 10.

${ }^{8}$ Колодяжний Євген - другий після Василя Покровського керівник Сумської “Просвіти”. В 1918 р. він працював юристом (на посаді податкового інспектора). Належав до партії українських соціалістівреволюціонерів і вважався “старим революційним робітником” (ДАСО. Ф. 2. Оп. 1. Спр. 36: 26-27). У квітні 1918 р. за ініціативи “Просвіти” був затверджений урядом УНР комісаром Сумського повіту. За Директорії 21 грудня 1918 р. Сумськими земськими повітовими зборами знову був обраний комісаром повіту і 26 грудня затверджений на цій посаді Харківським губернським комісаром. 310 березня по 15 липня 1920 р. виконував обов'язки Подільського губернського комісара також від Директорії УНР. У міжвоєнний період проживав на території Польщі, у м. Рівне, керував книгарнею “Наша культура” та працював у магістраті. Далі жив у Німеччині, де й помер. - Док. № 10.

${ }^{9}$ Головою Ради Міністрів Української Держави був тоді Федір Лизогуб (1851-1928). - Док. № 13. 